\title{
Entrepreneurial Training of Low-Income Women Micro Enterprises in the Service Sector in Malaysia: Understanding the Problems and Challenges
}

\author{
${ }^{*}$ Nor Asiah Omar'1, Muhamad Azrin Nazri², Che Aniza Che Wel ${ }^{1}$ \\ ${ }^{1}$ The National University of Malaysia, Malaysia \\ ${ }^{2}$ Asia Pacific University of Technology and Innovation, Malaysia \\ *norasiah@ukm.my
}

\begin{abstract}
Most of the low-income women who are involved in micro enterprises (MEs) in Malaysia have low business sustainability due to low confidence and business skills. Current training programmes offered to the low-income segments have limitations such as too general training contents, expensive fees etc. The current assistance schemes given by the government have fallen into the trap of charity and high cost. Nevertheless, women who have undergone some kind of entrepreneurial training faced lesser obstacles and produced higher business growth than those who have never attended training. Despite the increase in the number of research involving women entrepreneurs, there is lacked of research about entrepreneurial training involving low-income women micro enterprises (MEs) in service businesses in Malaysia. For this reason, little knowledge exists regarding the entrepreneurial training for MEs and service sector, particularly in Malaysia. Therefore, this study intends to explore the problems and challenges relate to entrepreneurial training among low-income women MEs in service business. To achieve the objectives, this study will employ qualitative methods using focus groups and interviews targeted at low-income women MEs in the service sector in Malaysia. This study delivers an important contribution to our understanding of how to develop a better entrepreneurial training to low-income women MEs in service sectors in Malaysia.
\end{abstract}

Keywords: Women, entrepreneurial training, micro enterprise, low-income, entrepreneurs

\section{Introduction}

In recent years, the Malaysian government's development strategy has shifted to the promotion of small and medium enterprises (SMEs). According to a statistical report released by the Ministry of Entrepreneur and Cooperative Development (MECD), the number of individuals who become entrepreneurs is increasing. During the period of 1995 to 2000, the number of entrepreneurs increased at an incremental rate of around 75.79 per cent. Based on the Census of Establishments \& Enterprises 2005 by the Department of Statistics Malaysia, out of the 548,267 SMEs established in Malaysia, 435,324 (78.7\%) business establishments were contributed by the Micro Enterprises (MEs). About 16\% are women-owned enterprises (Teoh \& Chong, 2008). The MEs involved in all three main sectors in Malaysia, namely: services, agriculture and manufacturing. Among all the three sectors, most of the MEs are involved in services (381,585 MEs, 87.7\%) followed by agriculture (31,838 MEs, 7.3\%) and manufacturing (21,516 MEs, 4.9\%) (SME Corp Malaysia, 2012). According to a report by the Companies Commission of Malaysia in 2001, food and beverage recorded the highest registered business activities for the year.

Although the involvement of women entrepreneurs across the country can lead to economic growth and can eradicate poverty, the involvement of women in business is still very low compared to male counterparts in Malaysia (Idris, 2010). Most women entrepreneurs, particularly those in rural areas are involved in informal sectors of the economy and low-productivity activities. High level of poverty and constrained livelihood opportunities in rural areas remain a continuing challenge in Malaysia, particularly for women. Limited ability among women to compete for employment opportunities and low levels of education severely constraint access to employment opportunity for most women at the rural areas. Within this context, the participation of women in a formal sector of the economy such as in micro-small enterprises is still limited. Based on a research by Malaysia Central Bank in 2001, small and medium enterprises need continuous assistance in various areas relate to management, business and technical skills. In franchising business for 
example, franchisors have offered various training programs continuously to franchisee entrepreneurs and these assistances have increase franchisees efficiency, reduced conflict and meet current challenges (Hanafiah \& Che Senik, 2003).

As male entrepreneurs, women entrepreneurs also need support in participating in entrepreneurial activities. In France, start-up capital from Microfinance Institutions enables a greater number of women to start their own business (Brana, 2013). Moreover, lack of support for micro enterprises (MEs) development such as entrepreneurial training and facilities for women MEs development is a crucial gender concern. It is reported that the difficulties of women entrepreneurs, and the challenges faced by them are different from male entrepreneurs (Ince, 2009). Based on past studies among the major concerns mentioned by women micro entrepreneurs were the lack of appropriate and suitable entrepreneurial training (Kim, 1996; Rosa, Carter, \& Hamilton, 1996). Malaysia is one of the very few countries, which established the Ministry of Entrepreneur and Cooperative Development (MECD) in May 1995, and the Ministry of Women, Family and Community Development (MWFCD) in 2001. Together; these ministries oversee the growth and development of existing and potential women entrepreneurs in the country. Various government grants and funds are made available to the low-income women entrepreneurs through many programs provided by SME Corporation Malaysia (SMECORP), TEKUN Programme, Amanah Ikhtiar Malaysia (AIM) and Program 1Azam.

Interestingly, it was reported that women who underwent some kind of entrepreneurial training faced lesser obstacles and produced higher business growth than those who have never attended training (Ganesan, Kaur, \& Maheshwari, 2002). Thus, several researchers have acknowledged the need to study the role of training and education on the performance of women entrepreneurship (Bhardwaj, 2013; Lassithiotaki, 2011). Based on the study by Dumas (2001), training provided to low-income women has indeed helped the participants to launch their own businesses, to empower them to achieve self-sufficiency through entrepreneurship and to advance the economic health throughout the country through micro enterprise and job creation. Therefore, this research would like to address the low business sustainability, confidence and entrepreneurial skills among low-income women MEs in Malaysia particular those who are involved in the service sector. Within the marketing literature, there are many differences between products and services that are often been labelled as characteristics of services (Kotler \& Keller, 2012). The three key characteristics that distinguish services from products are intangibility, heterogeneity and simultaneity (Trott, 2008). For example, due to its intangibility in nature, it is often easier and quicker to develop and modify services compared to tangible products. However, it is difficult for entrepreneurs to test service during development stage and produce a radical innovation in the processes and procedures (Trott, 2008).

In fact, it is noted by De Brentani (1991) that service firms have much fewer incentives to employ costly and time-consuming product development activities compared to physical product firms, partly due to ease of imitation and partly due to the difficulty of attaining long-term competitive edge. Moreover, services are produced and consumed simultaneously. For this reason, in service businesses, the operation's staffs play both an operational and a marketing role. Similarly, in services, the involvement of customers in the process and the interaction with staff will influence the service experience (Zeithaml \& Bitner, 2003). Despite, the fact that the service sector is unique and has become an extremely large part of the modern economy (Lee, Pitt, Berthon, \& Prendergast, 1996; Oldenboom \& Abratt, 2000), research related to services is still limited (Hollenstein, 2003). The importance of type and amount of skills toward economic growth can be traced back to past literatures (i.e. Hanushek \& Woessman, 2008; Jimenez et al., 2012; Lucas, 1988; Romer, 1986). Similarly, Gupta \& Sharma (2011) found that there is a significant correlation between entrepreneurial training in developing the prerequisite skills and business performance. Although Abdul Rahman et al. (2011) assess the preferred learning styles of small medium enterprise (SME) among rural entrepreneurs in Malaysia; the study was not dealt with low-income women MEs in service businesses. Furthermore, there have been very limited studies from developing countries involving micro enterprise (Terjesen et al. 2013; Rao, 2014). Despite the high number of involvement among MEs in the service sector, it is more challenging for entrepreneurs to manage services due to its unique characteristics (Cowell, 1988; Trott, 2008).

Considering of the above gap, the purpose of this study is: 
- To explore challenges' encounter by low-income women MEs in the service sectors in Malaysia

- To identify the specific training needs and supports that are important and relevant to low-income women micro entrepreneurs, especially those in the early stage in sustaining their business

- To identify the difficulties faced by low-income women MEs in attending entrepreneurial training

- To explore the benefits of attending entrepreneurial training among low-income women MEs

This study suggests improvements to be made to the current entrepreneurial training for low-income women MEs in service businesses provided by the Malaysia government as well as other professional bodies responsible for entrepreneurial training and course. This study provides researchers, policy makers and academicians with better insights on the specifically designed entrepreneurial training for low-income women that involved in MEs.

\section{Literature Review}

The Malaysian economy has managed to grow in spite of the global economic crisis. Through a tough fiscalpolicy stance for the 2011 budget and the Tenth Malaysia Plan (10MP), the government has adopted few transformation programs that aim towards social development, including raising the quality of human capital through improvement in education sectors, building equality of income and improving the basic rural infrastructure. Based on a data monitor (2010) report, the country's economy is estimated to grow by $5 \%$. Despite this, the unemployment rate increased from $2.9 \%$ in 2002 to $3.3 \%$ in 2008 . The continuing decline in employment and career opportunities increasingly requires people to achieve their social and career aspirations through self-employment and entrepreneurship activities. Therefore, to increase the employment rate and capacity building, the government's development strategy has shifted to the promotion of small and medium enterprise (SME) such as the launched of 1 Azam Movement (Gerakan 1Azam) to facilitate job placement and the establishment of small business and agricultural projects. According to Ponnusamy and Saleh (2006), support for SME growth and competitiveness has become mandatory following the 1997-1998 Malaysia financial crisis. Moreover, government grants and funds such as the SME Corporation (SMECORP), Amanah Ikhtiar Malaysia (AIM), and Ministry of Women, Family and Community Development (MWFCD) were introduced to encourage more Malaysian women to become entrepreneurs. According to Bernama (17 March 2010), the government targets to create 4,000 women entrepreneurs among the hard core poor, who are those with a household monthly income of less than $£ 96$ (MYR440), by 2012.

Despite the assistance given by the government, the difficulties of women entrepreneurs and the challenges faced by them are different from male entrepreneurs. Based on past studies (Buttner \& Moore, 1997; Kim, 1996; Rosa et al., 1996) among the major concerns mentioned by women micro entrepreneurs were the lack of appropriate and suitable entrepreneurial training and advisory services that can help them to improve their business and technical skills. Further, Nawaz (2012:1) found that major problems faced by women entrepreneurs in Bangladesh were "lack of knowledge and experience in marketing of products, poor managerial and technical skills, as well as low amounts of capital, huge interest burden, and social and cultural obstacles". In France, Robinson and Stubberud (2011) found that women were more likely to report lower levels of profitability and expected to cease operations. Next, according to another study by (Arayesh, 2011), skill barriers, economic and legal obstacles were among the biggest problems for women entrepreneur in their stage of business development. When interviewed 90 female micro entrepreneurs in Ethiopia, Singh and Belwal (2008) found that most of the problems were getting financial assistance, lack of entrepreneurial and management competency, problems in finding the right target markets and distribution networks, limited opportunities for promotion and participation, limited support by government and support institution, and absence of technological know-how.

Previous studies (ie. Ahmad, 2012; Day-Hookoomsing \& Essoo, 2003; Ganesan et al., 2002; Hisrich \& Fan, 1991; Kim, 1996; Lee-Gosselin \& Grise, 1990; Shim \& Eastlick, 1998; Ssendi \& Anderson, 2009) suggested common problems faced by women micro entrepreneurs were related to: business-related skills and entrepreneurial credential, the ability to raise capital and obtain credits, managing debt, access to working capital, infrastructure, networking, low confidence, and gender problem of not being taken as seriously as 
men (see Table 1 for common problems among low-income women MEs). According to Barwa (2003) and Dumas (2001), the entrepreneurial training designed for the women micro entrepreneurs need to consider the barriers that women entrepreneurs face relate to work-home conflict-the dual responsibility of managing business and family. Interestingly, it is also noted by Barakat (2011) that most women entrepreneurs have less self-efficacious and low self-confidence, which leads to serious problems among women to be a successful entrepreneur.

Table 1: List of Common Problems among Low-Income Women Entrepreneurs

\begin{tabular}{|c|c|}
\hline Problems & Sources \\
\hline Low confidence & $\begin{array}{c}\text { Barakat (2011); Collerette \& Aubry (1990) } \\
\text { Lack of business related skills and entrepreneurial credentials } \\
\text { Maternal responsibility-managing work and family }\end{array}$ \\
\hline $\begin{array}{c}\text { Capital (1996); Ssendi \& Anderson (2009); Teoh \& Chong } \\
\text { Do not perceive equal opportunity } \\
\text { Networking } \\
\text { IT }\end{array}$ & $\begin{array}{c}\text { Pellegrino \& Reece (1982); Still \& Walker (2006) } \\
\text { Koshal et al. (1998) }\end{array}$ \\
\hline $\begin{array}{c}\text { Accessing information } \\
\text { Aldrich (1989); Teoh \& Chong (2008) } \\
\text { Martin \& Wright (2005) }\end{array}$ \\
\hline
\end{tabular}

\section{Methodology}

Based on its objectives this study adopts a multi-method research design. To achieve the research objectives, this research is divided into two stages.

Stage 1- Literature Review, Key Informant Survey and Discussion with Practitioners: The research process began with a thorough review of regional publication and past studies related to entrepreneurship, entrepreneurship education, social entrepreneurship, and women entrepreneurs, challenges encountered in running enterprises in Malaysia as well as in other countries (Ahmad, 2011; Bull, 1995; Timmons \& Spinelli, 2009). The purpose of having extensive literature review is to understand the current issues involving women MEs and to integrate the relevant information into the focus group and interview (stage 2). The literature study was further complemented by several unstructured interviews and informal discussions with the few government officers and NGOs such as MARA, SME Corp. Malaysia and Amanah Ikhtiar Malaysia (AIM). The study chose unstructured face-to-face interviews among other types of qualitative methods because it has the potential of providing rich data, especially on issues, which were still exploratory in nature (Sekaran, 2003). The discussion focused on issues pertaining to common problems and issues faced by women entrepreneurs, particularly those involved in micro business. The outcomes of these discussions were helpful in defining the challenges and type of training relevant to the women entrepreneurs. Moreover, the discussion also helped the author in providing practical recommendations concerning data collection method. Experience survey, which is also called as the key informant surveys, was employed during this study in an attempt to form insights from those that are familiar with the subject matter under study (Churchill \& Iacobucci, 2002). Informal discussions were held individually with two officers (from small and medium industry SMECORP) who have been actively involved in managing micro business.

Stage 2: Focus Groups and Interviews among Low-Income Women MEs In Service Businesses: Focus groups are generally the first step in a research process and have proven to be productive for generating information for exploratory research (Collins \& Hussey, 2003). According to Collins and Hussey (2003), a focus group combines both interviewing and observation. Zikmund (2003) defined focus group as: "an unstructured, free-flowing discussion with a small group of people" (p.224). The focus group sessions are aimed at obtaining respondents' impressions, interpretations, and opinions, as the members talk about their business. Moreover, it allows the researcher to be familiarising with the wording the participants used to describe their business and experience. Invitations to participate in the focus group session were sent to a 
selected group of low-income women ME that are involved in the 1Azam programme - collaboration programme between National Council of Women Organizations Malaysia (NCWO) and The National University of Malaysia (UKM). Eight women were randomly selected this is to ensure that the participants have the experience pertinent to the subject matter and have the capability to articulate their experience and knowledge during the discussion sessions. The group sessions were conducted in January 2012. The focus discussions were executed personally by the author as the moderator and lasted approximately 50-90 minutes.

Before the session, the group members were briefed on the aims and objectives of the market research. The focus group's session was conducted as follows: The facilitator welcomed the participants and explained the aims/objectives of the focus group session. Then the facilitator discussed the overarching question during the group session, which was, 'What do you perceive to be the factors of a successful entrepreneurial training and the challenges of attending entrepreneurial training among low-income women MEs'. The group session started with a brainstorming session. We recorded all focus group discussions and subsequently replay transcription, and analysis. Two lecturers with backgrounds in both marketing and entrepreneurship then judged the items for representativeness. Discrepancies in interpretation between both experts were solved based on an in-depth bilateral discussion. Given the exploratory nature of the research, a qualitative approach using an in-depth personal interviews were undertaken to further understand the challenges and needs of low-income women MEs in Malaysia. The discussion will focus on issues pertaining to common problems and issues faced by low-income women MEs in service businesses. It is expected that the focus group as well as the interview will be helpful in defining the challenges and type of training relevant to the low-income women MEs in service businesses.

According to Ahmad (2011)Ahmad (2011), becoming an entrepreneur is a complex decision; therefore, interviews were considered to be the most suitable method to uncover the hidden issues that could go beyond the usual cliché's about women entrepreneurs. Prior to the interviews, a consent letter was submitted to NCWO to obtain consent for an interview between the participants of Program 1Azam. 20 women who had started micro business at home under the 1Azam programme were selected randomly. The procedure was a simple process whereby the participants were first asked if she had already started a small business at home. Those who answered "Yes" were included as sample and those who answered "No" were excluded. After selecting the sample group, a set of questionnaires was developed to interview the participants. A structured interviewer session was conducted in February 2012. Respondents were asked about some personal questions and questions related to their business experience. Although the sample size is small, it is considered acceptable for an exploratory study (Jamali, 2009). The interviews were conducted in Bahasa Malaysia. Each interview lasted between one to two hours was tape recorded with the approval of the interviewees and then transcribed (Stockdale, 2002).

The interview was recorded using a digital recorder and catalogued as per ethics requirements. These interviews were then transcribed for data analysis. The participants were initially screened for suitability. The participants were chosen from a wide range of business, including food, beauty care, tailoring, and hair dresser. To ensure the validity to the results, this study established descriptive and content validity. Descriptive validity was established after the twenty interviews, the themes were repetitive indicating 'saturation'. In case of content validity, it was proven because the interviewees were able to provide their opinion in similar statements (Guan Gan et al., 2006). The data was analysed using NVivo. After about 20 interviews, the themes were repetitive and possible to 'code' the interview data under common themes identified. The grouping was achieved by creating 'tree' structures using NVivo and then aggregating the free nodes (or themes) into these trees.

\section{Results}

Demographics Profile of Respondents: Descriptive analysis was applied to obtain the percentages and frequencies to present the demographic profile. Table 2 presents a detailed breakdown of the participants' demographic characteristics. As indicated in Table 2 the major age group was the 30-39 years of age group. This group of 9 respondents accounted for $45 \%$ of the respondents. The second significant age group was the 
40-49 years group, which representing 35\% of the respondents. In terms of ethnicity, the major ethnic group of respondents was the Malay group (55\%) and followed with Indian (30\%). 65\% participants were high school holders, and only $10 \%$ had received some college education (diploma \& certification). The marital profile of the participants revealed that half of the participants were single mother. These numbers indicate that most of these women are single mother heads of households with dependent children to support. In terms of the nature of business, the majority of the respondents are involved in food business (35\%), followed by tailoring (30\%) and beauty care/hairdressing business (15\%) (Refer to Figure 1).

Figure 1: Nature of Business

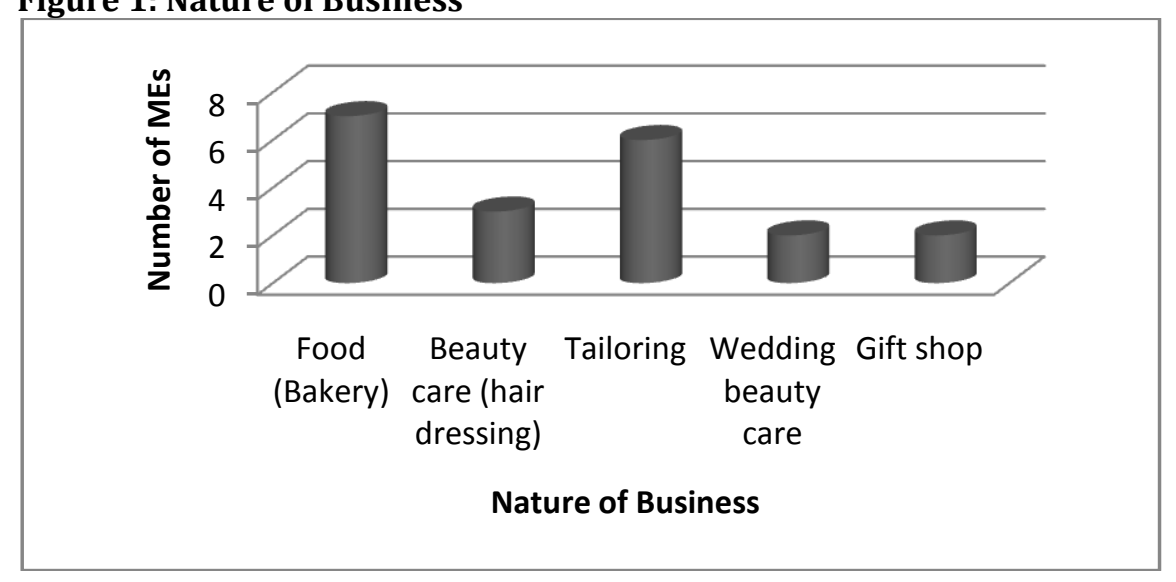

Table 2: Descriptions of the respondents ( $n=20)$

\begin{tabular}{llll}
\hline & & Number of Respondents & $\mathbf{\%}$ \\
\hline Gender & Female & 20 & 100 \\
Marital status & Single & - & - \\
& Married without Children & - & - \\
& Married with Children & 10 & 50 \\
& Widow/Divorce/Separate & 10 & 50 \\
Age & $20-29$ years old & 2 & 10 \\
& $30-39$ years old & 9 & 45 \\
& $40-49$ years old & 7 & 35 \\
Ethnic background & $50-59$ years old & 2 & 10 \\
& 60 years old and above & - & - \\
Highest & Malay & 11 & 55 \\
achievement & Chinese & 3 & 15 \\
& Indian & 6 & 30 \\
Type of business involved & Food & 5 & 25 \\
& Primary school or below & 5 & 65 \\
& High School & 13 & 10 \\
& Certificate/Diploma & 2 & 45 \\
\hline
\end{tabular}

Findings: The present section will present the results based upon the research objectives of the study.

Research Objective 1-To explore the challenges' encounter by low-income women MEs in the service sectors in Malaysia: The study gives an elaborate list of five drivers for women to involve in micro business 
(refer to Figure 2). It was seen that almost half of the respondents (45\%) stated desire to support family as main drivers to start business. This was followed by lack of employment opportunities and desire for independent and flexibility working time. Some of the women further mentioned that having relevant skills and experience also motivated them to initiate their own business. The results are in line with past studies on entrepreneurial motivation which include: the need for independence and autonomy (Reynold \& Miller, 1988; Scheinberg \& MacMillan, 1988),

\section{Figure 2: Drivers to Involve in Business}

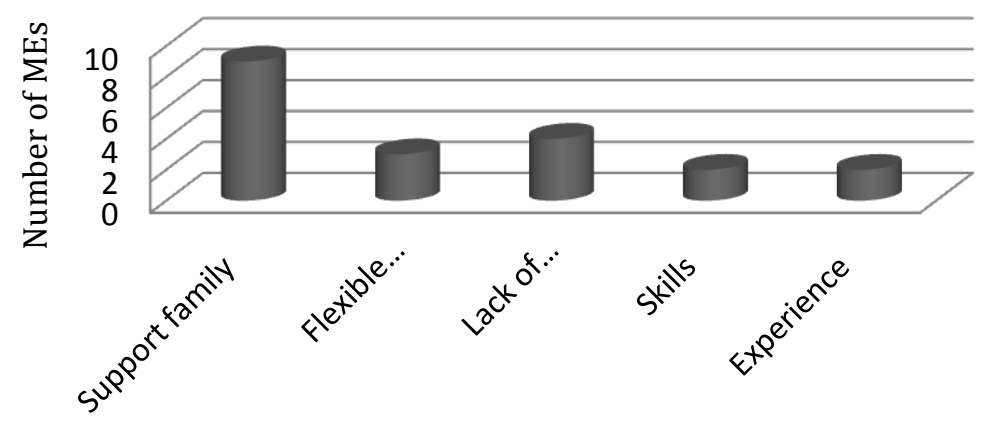

With regard to challenges encountered by low-income women MEs, this study highlight ten broad categories of problems/challenges faced by women MEs (refer to Figure 3). Almost all considered finance and marketing (90\% and $85 \%$ respectively) as the most challenging factors in managing their business. Studies have shown that one of the key challenges faced by women entrepreneurs are related to advertising and promoting products (Patterson \& Mavin, 2009). Since majorities of the respondents are low income, they do experience difficulties and often fail in getting loan or financial support. In addition not having collateral also prevents them from getting financial support to expand their business. Due to lack of financial support, a majority of the women used manual equipment operated by hand instead of using electronically operated equipment. Almost $40 \%$ of them mentioned that they needed machines (electronic sewing machines, bigger oven and mixer) in order to move them away from slow manual processes. Besides, most of the participants also mentioned the difficulties of not having a computer at home for them to explore into online marketing. In terms of marketing, regardless of the business stages (early start-up or growth) majority of the women noted that marketing as one of their biggest challenges as they have to compete with establish competitors. Besides that, gender-related aspect such as difficulties in networking and gender bias were also mentioned as common problems faced by them.

Figure 3: Challenges Involved in Micro Business among Women Entrepreneurs



Types of Challenges 
Most of the major constraints/challenges that prevented low-income women MEs from becoming successful women entrepreneurs were more focusing to the external factors. The data indicates that the greatest challenges facing most of the women MEs is lacked of funds and infrastructure. Some example text passages are given to illustrate this:

Respondent 1: I find it difficult to expand my business most of time I managed to borrow money from family and 'pawning' small jewellery that I have, these are something I do not want to do but I have no other source to support my children for school......there were also cases where I have to reject order made by customers due to limited bakery equipment that I have. I am afraid I will not be able to meet customer demand then the customer will become angry and disappointed with me. I always tell my customers if I cannot take their order.

Respondent 2: I received complaints from my neighbour who stay in the same flat that I always disturbed them for making lots of noise. I have to use 'lesung' (manual equipment like a mortar operated by hands and makes lots of noise) to make my 'pecal' (type of Malays foods) because I don't have machine to crush the ingredients. If I have the money the first thing I will do is buy a big blender and so that I can make more 'pecal' without disturbing my neighbour and also increase my production.

From the above text, it is indicated that the two respondents were highlighting the same theme, almost in similar terms. The reference is on 'infrastructure', 'funds' and what other common obstacles faced by women MEs

Research Objective 2-To identify the specific training needs and supports that are important and relevant to low-income women micro entrepreneurs, especially those in the early stage in sustaining their business: Figure 4 shows the types of training require by low-income women MEs. Generally, it can be concluded that the type of entrepreneurial training varies by stage and type of business. For example, those who are involved in food sectors urgently need helps on halal certification, branding and packaging. While, those involved in service need assistance in managing customer demand and supply, branding as well as quality control. While, a majority of the low-income micro entrepreneurs mentioned ICT, legal and costing as important elements to be included in the entrepreneurial training. With regard to marketing, product design, branding, packaging, halal certification and development of the website have left the product, and services remain as localised merchandise. It is therefore, important that the women are trained to produce products/services that have distinctive packaging and labelling which convey quality and standards at the local and international market.

\section{Figure 4: Types of Entrepreneurial Training}

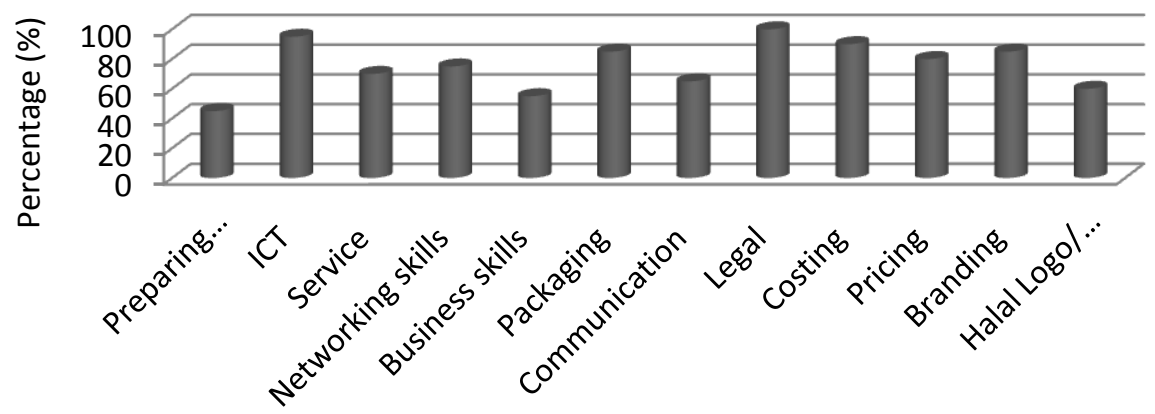

Type pf Entrepreneurial Coaching 
For example few of the participants mentioned:

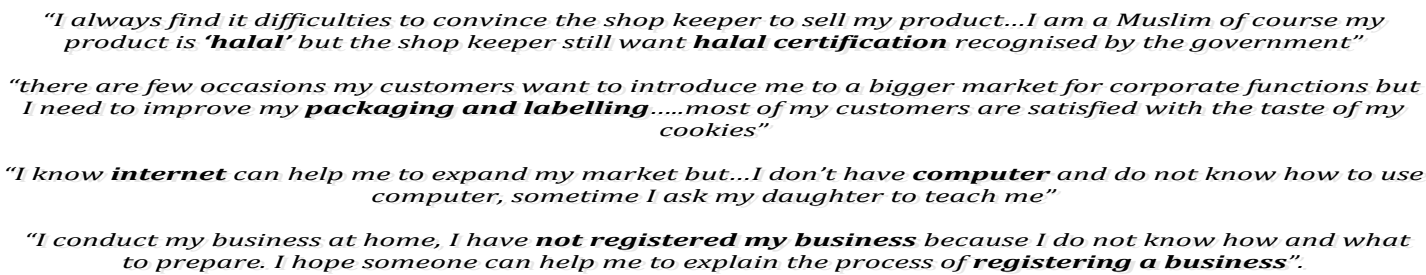

Objective 3-To identify the difficulties faced by low-income women MEs in attending entrepreneurial training: Almost all the women (90\%) faced the problem of losing their income if they attend the entrepreneurial training/course to upgrade their entrepreneurial skills (refer to Figure 5). It was seen that most of them manage their business on their own without having supportive staffs or partners to help them. Thus, they will have to incur losses if they want to attend any training. Interestingly, the majority of the women (85\%) also mentioned that there will be no one taking care of their young children if they were to attend longer entrepreneurial training. Most of the women start their business at their home for some specific reason of: able to combine both work and family care responsibilities and capable of run business and reduce overheads involved in leasing premises; hence, there is a need to understand that most of the participants consider family as their main priorities, especially for those single mothers.

\section{Figure 5: Problems Attending Entrepreneurship Training}

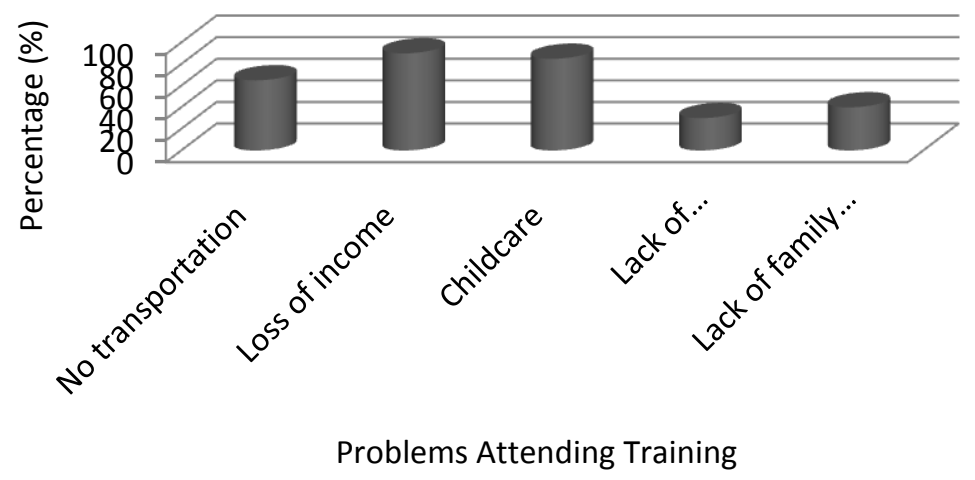

Objective 4-To explore the benefits of attending entrepreneurial training among low-income women MEs: To understand the effectiveness of the training session to the participant, the respondents mentioned obtaining several benefits by attending the entrepreneurial training such as marketing skills, networking skills, time management skills and increase their self-confidence (refer to Figure 6). Some participants mentioned:

"The program was offered at no cost, but I have learned about how to set price for my tailoring business and how to add value and differentiate my service from others.... "

"The program has its own unique strength ........as all the trainers are women most of them understand our problem-only a women will understand another women problems" 
One of the respondents also explains another dimension of her gain in term of confidence and motivation. She says:

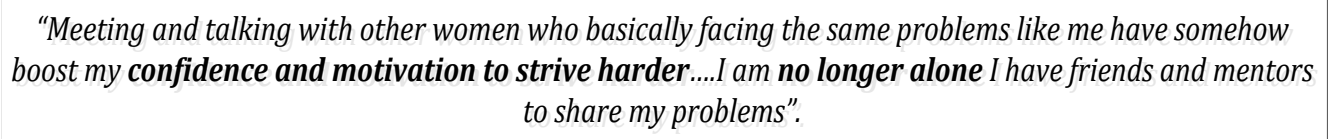

"Meeting and talking with other women who basically facing the same problems like me have somehow boost my confidence and motivation to strive harder...I am no longer alone I have friends and mentors to share my problems".

Figure 6: Benefits from Entrepreneurial Training

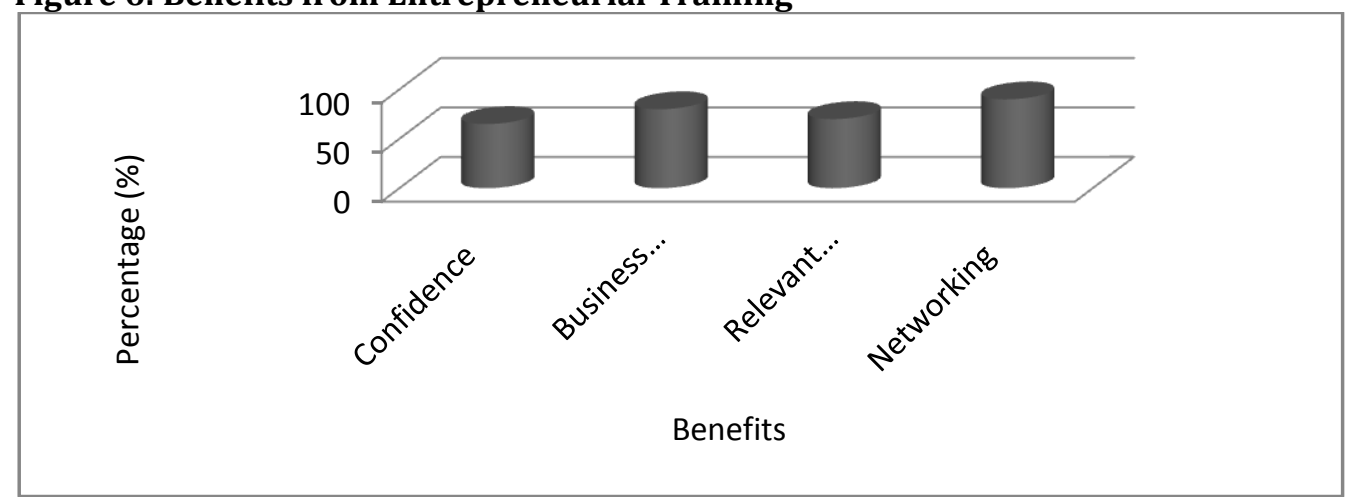

This is supported in the past studies that suggested that entrepreneurship training and education are significantly related to one's knowledge and confidence in managing a business (DeTienne \& Chandler, 2004).

\section{Implications and Conclusion}

Responses from many of the participants provide positive feedback towards the initial entrepreneurial training, and coaching delivered to low-income women MEs. However, to make the entrepreneurship training/course more effective and relevant to the target participants, there are several recommendations based on the observations, suggestions and findings from this study. The results will serve as a guide to other entrepreneurial training providers to improve its service in providing a value-added entrepreneurial mentoring and coaching to low-income women MEs in Malaysia. Based on the findings, there are ten improvements that can be implemented. The improvements are as follows:

- As most women entrepreneurs need to cope between family and work, it is vital for the training providers to consider providing a child care facility. The function of the day-care centres is to take care the young ones this is to facilitate women with children to participate and attend the entrepreneurial mentoring and coaching. Besides that, the centre also needs to consider the timing of the training to be conducted on weekends and evening as most of the participants found it difficult to attend the training during the day.

- To include in the training modules few important and relevant contents such as: exposure to the benefits of technology (online marketing), and hands-on Internet assistance and web marketing.

- To provide transportation for low-income women MEs if the training is to be conducted far from their home.

- Get the involvement from government regulatory agencies for examples: The Department of the Advancement of Islam Malaysia (JAKIM) for Halal Certifications; Certified Management bodies (SIRIM) quality recognition for ISO; Malaysia Packaging Industry; Financial institutions - requirements and documentations for a bank loan.

- Include slot on motivation-invite successful women entrepreneurs who start with a small business to uplift participants' motivations. 
- Attempts to develop a variety of skills, which include business skills, leadership skills, communication skills, and also personal supports in helping low-income communities out from the poverty cycle.

- Encourage peer support among the participants as well as with the mentors. This is to encourage them to learn from one another and share their contacts and networks.

- Implement mentor-protégé method in the training by including continuous guidance, especially for those who just start a business. A mentor will be engaged to a real case and exposed to real entrepreneurship activities and will be assigned to a protégé. Regular meetings and follow-up need to be conducted to monitor the progress of each protégé. Moreover, the mentors also need to build relationship and trust among the participants for them to share their ideas.

- Need to consider ethnic diversity among participants in developing the training modules and programs.

- Need to consider the diverse on the education level among participants in conducting the training session. Those who do not finish high school may find it difficult to cope with costing and technical aspects. Hence, need to have a session that can provide basis knowledge and personal life skills to those with a low education level.

Acknowledgement: the authors thank Dr. Faridah shahadan, Dr. Madeline berma and teman 1azam ukmncwo for their assistance in this study

\section{References}

Abdul-Rahman, R., Salleh, Z. \& Loh Rahim, M. H. (2011). Entrepreneurs continuous learning: assessing the preferred learning styles of SME rural entrepreneurs in Malaysia. In The 8th SMEs in a Global Economy Conference 2011. Kuala Lumpur.

Ahmad, S. Z. (2011). Evidence of the characteristics of women entrepreneurs in the Kingdom of Saudi Arabia: an empirical investigation. International Journal of Gender and Entrepreneurship, 3(2), 123-143.

Ahmad, S. Z. (2012). Microfinance for women micro and small-scale entrepreneurs in Yemen: Achievements and challenges. International Journal of Entrepreneurship and Small Business, 16(1), 102-120.

Arayesh, B. (2011). Examine some of the problems and obstacles women university graduates in the field of business. Australian Journal of Basic and Applied Sciences, 5(7), 692-695.

Barakat, S. (2011). The fairer sex and entrepreneurship. United Kingdom: Cambridge Judge Business School.

Barwa, S. D. (2003). Impact of Start Your Business (SYB) training on women entrepreneurs in Vietnam. ILO Vietnam Working Paper Series, 1.

Bhardwaj, B. R. (2013). Impact of education and training on performance of women entrepreneurs: A study in emerging market context. Journal of Entrepreneurship in the Emerging Economics, 6(1), 38-52.

Brana, S. (2013). Microcredit: an answer to the gender problem in funding? Small Business Economics, 40(1), 87-100.

Bull, I. (1995). Entrepreneurship: perspectives on theory building. Pergamon Pr.

Buttner, E. H. \& Moore, D. P. (1997). Examine some of the problems and obstacles women university graduates in the field of business. Journal of Small Business Management, 35(1), 34.

Churchill, G. \& Iacobucci, D. (2002). Marketing Research: Methodological Foundation (8th ed.). South Western College.

Collins, J. \& Hussey, R. (2003). Business Research: a Practical Guide for Undergraduate and Postgraduate Students. New York: Paigrave Macmillan. New York: Palgrave Macmillan.

Collerette, P. \& Aubry, P. (1990). Socio-economic evolution of women business owners in Quebac (1987). Journal of Business Ethics, 9(4-5), 417-422.

Cowell, D. W. (1988). Business Research: a practical guide for undergraduate and postgraduate students. Journal of Marketing Management, 3(3), 296-312.

Day-Hookoomsing, P. \& Essoo, V. (2003). Promoting female entrepreneurship in Mauritius: Strategies in training and development. Women's entrepreneurship development and gender equality (WEDGE), SEED working paper; no. 58.

De Brentani, U. (1991). Success factors in developing new business services. European Journal of Marketing, 25(2), 33-59. 
DeTienne, D. \& Chandler, G. (2004). Opportunity identification and its role in the entrepreneurial classroom: A pedagogical approach and empirical test. Academy of Management Learning and Education, 3(3), 242-257.

Dumas, C. (2001). Micro enterprise training for low-income women: The case of the community entrepreneurs programme. Journal of Entrepreneurship, 10(1), 17-42.

Ganesan, R., Kaur, D. \& Maheshwari, R. C. (2002). Women entrepreneurs problems and prospects. Journal of Entrepreneurship, 11(1), 75-93.

Guan Gan, G. C., Ryan, C. \& Gururajan, R. (2006). The effects of culture on knowledge management practice: A qualitative case study of MSC status companies. Kajian Malaysia, XXIV(1\&2).

Hanushek, E. A. \& Woessmann, L. (2008). The role of cognitive skills in economic development," Journal of Economic Literature, 46(3), 607-68.

Hanafiah, M. \& Che Senik, Z. (2003). Entrepreneurial training and entrepreneurs education: an empirical evidence in franchising business. In Proceeding 12th International Conference on Internationalizing Entrepreneurship Education and Training, (pp. 161-184).

Hisrich, R. D. \& Fan, Z. (1991). Women entrepreneurs in the People's Republic of China: an exploratory study. Journal of Managerial Psychology, 6(3), 3-12.

Hollenstein, H. (2003). Innovation modes in the Swiss service sector: a cluster analysis based on firm-level data. Research Policy, 32(5), 845-863.

Idris, N. A. (2010). Daya saing usahawan wanita Melayu menghadapi cabaran globalisasi. Prosiding Persidangan Kebangsaan Pusat Pengajian Sosial, Pembangunan \& Persekitaran "Cabaran Pembangunan Dilema Persekitaran" 12 - 13 September 2003, UKM, Bangi, (September 2003).

Ince, M. (2009). A socio-economic perspective on women entrepreneurs: Evidence from Turkey. Икономически Изследвания, 4, 138-166.

Jalil, S. (2010). Four thousands entrepreneurs to be created from the hard core poor. Bernama 17 March, 2010. Retrieved from www.bernama.com

Jamali, D. (2009). Constraints and opportunities facing women entrepreneurs in developing countries: A relational perspective. Gender in Management: An International Journal, 24(4), 232-251.

Jimenez, E., Nguyen, V. \& Patrinos, H. A. (2012). Stuck in the middle? Human capital development and economic growth in Malaysia and Thailand. Policy Research Working Paper The World Bank, Human Development Network Education Unit.

Kim, T. S. (1996). Women Entrepreneurs of Singapore. In Entrepreneurs, entrepreneurship and enterprising culture. Singapore: Addison-Wesley.

Kotler, P. \& Keller, K. L. (2012). Marketing Management (14ed ed., p. 131). England: Pearson Education Limited.

Lassithiotaki, A. (2011). Rural women and entrepreneurship: A case study in Heraklion Crete prefecture, Greece. Journal of Developmental Entrepreneurship, 16(2), 269-284.

Lee, C. W., Pitt, L., Berthon, P. \& Prendergast, G. (1996). Country of origin effects: perspectives from the literature revisited. Henley Management College, Henley Research Centre.

Lee-Gosselin, H. \& Grise, J. (1990). Are women owner-managers challenging our definitions of entrepreneurship? An in-depth survey. Journal of Business Ethics, 9(4-5), 423-433.

Lucas, R. (1988). On the Mechanics of Economic Development. Journal of Monetary Economics, 22(1), 3-42.

Nawaz, F. (2012). Problems of woman entrepreneurship development in Bangladesh: A case study of RAKUB. Pertanika Journal of Social Sciences \& Humanities, 20(3).

Oldenboom, N. \& Abratt, R. (2000). Success and failure factors in developing new banking and insurance services in South Africa. International Journal of Bank Marketing, 18(5), 233-245.

Patterson, N. \& Mavin, S. (2009). Wings. International Small Business Journal, 27(2), 173-192.

Pellerino, E. T. \& Reece, B. L. (1982). Perceived formative and operational problems encountered by female entrepreneurs in retail and service firm. Journal of Small Business Management, 2, 15-24.

Ponnusamy, V. \& Saleh, E. S. (2006). SMEs in Malaysia: Policies, incentives and challenges. In A. S. Saleh \& N. 0. Ndubisi (Eds.), Small \& Medium Enterprises (SMEs): Malaysian \& Global Perspectives. Pearson Prentice Hall.

Rao, S. (2014). Nurturing entrepreneur women: Insights from a developing country. Journal of Entrepreneurship in Emerging Economics, 6(3), 268-297. 
Reynolds, P. D. \& Miller, B. (1988). 1988 Minnesota new firms study: An exploration of new firms and their economic contributions, Centre for Urban and Regional Affairs, Minneapolis, MN.

Robinson, S. \& Stubberud, H. A. (2011). Gender differences in entrepreneurs' perceived problems, profits and plans. International Journal of Entrepreneurship, 15, 25-44.

Romer, P. (1986). Increasing Returns and Long-run Growth. Journal of Political Economy, 94, 1002-1037.

Rosa, P., Carter, S. \& Hamilton, D. (1996). Gender as a determinant of small business performance: insights from a British study. Small Business Economics, 8(6), 25-44.

Sekaran, U. (2003). Research Methods for Business: A Skill Building Approach. New York: John Willey and Sons.

Scheinberg, S. \& MacMillan, I. C. (1988). An 11 country study of motivations to start a business. Frontiers of Entrepreneurship Research, 2, 669-687.

Shim, S. \& Eastlick, M. A. (1998). Characteristics of Hispanic female business owners: an exploratory study. Journal of Small Business Management, 36(3), 18-36.

Singh, G. \& Belwal, R. (2008). Entrepreneurship and SMEs in Ethiopia: Evaluating the role, prospects and problems faced by women in this emergent sector. Gender in Management: An International Journal, 23(2), 120-136.

Ssendi, L. \& Anderson, A. R. (2009). Tanzanian micro enterprises and Mmpact for poor rural women. Journal of Entrepreneurship, 18(1), 1-19.

Stockdale, A. (2002). Tools for digital audio recording in qualitative research. Social Research Update, 38(1-4).

Teoh, W. M. Y. \& Chong, S. C. (2008). Improving women entrepreneurs in small and medium enterprises in Malaysia: policy recommendations. Communications of the IBIMA, 2(5), 31-38.

Terjesen, S., Jolanda, H. \& Li, D. (2013). Comparative international entrepreneurship: A review and research agenda. Journal of Management, 20(10), 1-46.

Timmons, J. A. \& Spinelli, S. (2009). New Venture Creation: Entrepreneurship for the 21st Century. McGrawHill/Irwin.

Trott, P. (2008). Innovation Management and New Product Development (4th ed.). England: Financial Times/Prentice Hall.

Zeithaml, V. A. \& Bitner, M. J. (2003). Services Marketing: Integrating Customer Focus across the Firm (3rd ed.). New York: McGraw-Hill.

Zikmund, W. (2003). Business Research Methods. Ohio: Thompson South-Western. 